\title{
Assessment of suitability of local raw material resources for the manufacture of substrates for growing infrequent berry crops
}

\author{
Bortnik T. ${ }^{1}$, Gavryliuk V. ${ }^{2}$, Bortnik A. ${ }^{3}$ \\ Polisska Experimental Station of NSC «Institute for Soil Science and Agrochemistry Research named \\ after O.N. Sokolovsky» \\ 35 Shevchenko Str., Lutsk, Volyn oblast, 43001, Ukraine \\ e-mail: ${ }^{1}$ didkovtana@ gmail.com, ${ }^{2}$ gavrilyuk-v@ukr.net, ${ }^{3}$ bam.bortnik@gmail.com \\ ORCID: ${ }^{1} 0000-0002-8159-2479,{ }^{2} 0000-0003-3923-0842,{ }^{3} 0000-0003-4292-0481$
}

Goal. To develop a system for assessing the suitability of local raw materials for the manufacture of substrates suitable for growing rare berry crops. Methods. Dialectical - to assess the suitability of local raw materials for the manufacture of substrates taking into account the agrobiological characteristics of berry crops, analytical-statistical - to analyze available raw materials and industrial waste in the Volyn region, laboratory - to study the physicochemical properties of the main components of substrates (peat, sapropel). Results. A comprehensive assessment is made of the suitability of local raw materials of the Volyn region. The most promising and suitable types of local resources for the production of soil substrates are proposed, taking into account the agrobiological features of the growth and development of rare berry crops. It is fixed that the density of the substrate, the reaction of the soil solution, and the content of ash, nitrogen, phosphorus, and potassium have the greatest impact on the growth and development of rare berry crops during the growing season. A system is proposed for assessing the suitability of the main types of local raw materials (peat, sapropel) for the manufacture of soil substrates for growing rare berry crops, which is based on agrobiological characteristics of plants and takes into account the basic parameters. Conclusions. The proposed system for assessing the suitability of local raw materials for the manufacture of soil substrates makes it possible to quickly assess the suitability of the main types of substrate components (peat, sapropel) and, if necessary, to adjust the basic parameters.

Key words: peat, sapropel, agrobiological features, tall blueberry, edible honeysuckle. DOI: https://doi.org/10.31073/agrovisnyk202101-03

Today, agriculture is one of the priority sectors of Ukraine's economy. Its development contributes to improving the material well-being of the population, strengthening the economic and food security of the country, increasing exports of goods [1].

At all stages of agricultural development, the main activity is the production of crop and berry products [2]. Regarding the latter, its consumption in the world is increasing every year. This is justified by various reasons, including consumer preferences, the desire of the latter to lead a healthy lifestyle, the culture of consumption, and so on.

To maximize the introduction of rare crops, such as sea buckthorn, actinidia, chinese magnolia vine, turf (dogwood), chaenomeles, honeysuckle, blueberry, hawthorn, etc., an important issue is to create optimal conditions for their growth and development. In this aspect, the provision of favorable soil conditions is of paramount importance.

An alternative to the soil are newly created organic fertilizers and substrates, which are widely implemented for use as fertilizers and soils for growing seedlings. As a rule, their basis is peat, the success of further cultivation of plants depends on its quality and preparation [3].

Wide promotion in the domestic market of substrates prevents the fact that some manufacturers, to reduce costs, use low-quality mixtures and introduce mineral fertilizers by mechanical mixing $[4,5]$. In this case, gardeners are faced with the fact that excessive concentrations of some fertilizers lead to inhibition of root development during seed germination or rooting. Therefore, it is important to fully evaluate the properties of the substrate for the relevant production situation.

In recent years, there has been an increase in the consumption of organic products among the world's population, which has a positive effect on both human health and food security. Production of organic products using modern methods of agriculture, in accordance with the standards of organic production, allows the rational use of energy resources, reduces environmental pollution, obtaining high quality products and preserving and increasing soil fertility [5].

The fruit and berry industry is no exception in this case, so organic substrates made on the basis of peat are increasingly preferred for soilless plants cultivation. Such substrates are characterized by good air permeability and moisture retention, which creates conditions for active growth and development of crops [2]. 
An effective agricultural measure to improve the properties of peat-based substrates is the addition of various organic components that increase the content of nutrients - sapropel, manure, bird droppings, phosphorites, as well as components that improve air-holding capacity - straw, sawdust, bark etc.

Proper selection of nutrient substrate, which would provide a balanced plant nutrition during the growing season, is an important factor in the intensification of berry and crop production, ensuring high quality seedlings (seedlings) and berry products [7]. It is traditionally believed that soil fertility meets the nutrient needs of plants throughout the development period. However, with the expansion of the range of crops, there are more and more problems to ensure optimal conditions for development.

Given the growing demand for rare berry crops and ensuring the production of environmentally friendly products that would meet international requirements, confirmed by relevant certificates, it is increasingly important to develop organic substrates based on local raw materials that would ensure optimal growth and development of plants and ensure high productivity.

The purpose of research is to develop a system for assessing the suitability of local raw materials for the manufacture of substrates suitable for growing rare berry crops.

Materials and methods of research. Substantiation of scientific approaches for determining the criteria for selection of local raw materials for the manufacture of soil substrates was carried out by analyzing of scientific papers. The generalization of available local raw materials was based on the evaluation of statistical reports.

Research results and their discussion. The choice of the type of substrate for growing plants is one of the main conditions for obtaining quality planting material or seedlings.

In Volyn oblast as a substrate or as a component for its manufacture, you can use peat, sapropel, manure, slurry, urine, bird droppings, straw, organic waste. They contain macro- and microelements, physiologically active substances useful for plants, microorganisms, antibiotics, etc., promote a better course of biological processes.

Among the natural resources considered as a substrate or component for its manufacture, the first place belongs to peat. Peat is a phytophoric rock, formed over thousands of years from undecomposed plant residues (grasses, mosses and wood), which under conditions of high humidity and poor air exchange are only partially mineralized. The color of peat is given by organic matter, which determines its basic properties and gives porosity. This type is the best substrate for growing plants. It has a porous structure, high moisture and gas-absorbing properties, which create favorable for the development of the root system of plants water-air and antiseptic conditions, does not contain weed seeds and plant pathogens, 3-4 times lighter than mineral soil and quite cheap.

Peat contains up to $85-98 \%$ (on the dry matter) of organic matter, much of which decomposes slowly, creating the necessary concentration of carbon dioxide in the air for photosynthesis of plant mass.

Peat not only supports the structure of the soil and its water-mineral-air condition. It contains substances that plants use as a building material and as physiologically active substances that enhance metabolic processes.

The accumulated experience says about high efficiency of the greenhouse soils made on the basis of top undecomposed peat with degree of decomposition to $15-20 \%$ which contains not less than $60-75 \%$ of undecomposed sphagnum mosses and has the antiseptic properties caused by high metabolic acidity of $\mathrm{H}_{\text {обм }}(\mathrm{pH})=2,5-3,2$ and the presence of phenolic compounds.

Low nutrient content and high acidity of peat are not a disadvantage, it's a great advantage, as it allows the introduction of limestone and nutrients to create any level of nutrition in accordance with soil fertility and the needs of the crop being grown. Adjustment of the feed level becomes possible due to the high moisture and gas absorption capacity of sphagnum peat and its porosity.

Due to the anatomical structure the upper mosses are not subject of colmation for a long time, so greenhouse soils based on such peat can be used without replacement for 3-4 years, while soils based on transitional peat for 2-3 years and lowland for only 1-2 years.

As of 2020 year, 99 peat deposits have been explored in Volyn oblast, with reserves of 143,406 million tons of categories $A+B+C_{1}$ and 11,334 million tons of category $C_{2}(20,35 \%$ of total peat reserves in Ukraine) [8].

As of today, 7 peat deposits with reserves of 20,9 million tons have been put into operation. Peat production in 2017 (data for subsequent years are missing) amounted to 238 thousand tons (in addition, there are 209 peat deposits in oblast that are not included in the balance sheet; 188 of them are with resources of 173,39 million tons and 21 are with an area of up to 10 hectares of 443 thousand tons).

Reserves of lowland peat deposits in oblast are up to $90 \%$ of the total reserves. The presence of deposits of upper and mixed types was noted only in 7 peat deposits.

According to their location in the terrain, peat deposits occupy mainly the floodplains of the river Prypiat and its right tributaries - the rivers Turia, Stokhid and others, they are mostly narrow, often divided by land into many sections. The largest peat resources of Volyn oblast are concentrated in Liubeshiv district $15,3 \%$, in Manevychi - 13,3\%, in Kamin-Kashyrskyi - 10\% of the total resources.

Considering the volume of peat deposits in oblast and in Ukraine in general, it becomes appropriate to use it as the main component for the manufacture of substrates. 
There are 265 lakes with a total area of 13414,9 hectares in Volyn oblast. It indicates the prospect of accumulation of significant amounts of lake deposits - sapropels. They are a valuable natural resource of organic matter consisting of the remains of aquatic organisms and their decomposition products: algae, animals, higher plants. By their properties, sapropels are close to peat. The similarity between them in their organogenic origin, the presence of residues of organisms that have not reached full mineralization, a significant content of organic matter, in the conditions of formation. The age of bottom sediments in modern lakes according to the analysis and determination of the absolute age at ${ }^{14} \mathrm{C}$ does not exceed 12 thousand years.

Sapropels are characterized by a high content of total nitrogen - up to $45 \%$ on dry matter (up to $6 \%$ on organic). It is usually of organic origin, its ammonia form is $0,4-0,8 \%$, mobile $-6-35$; amino acids contain about $50 \%$ of total nitrogen. The chemical composition of nitrogen compounds is due to the presence of proteins that enter the sediments with the remains of plant and animal organisms, as well as a set of physico-chemical and microbiological transformations in the process of sapropel formation.

The phosphorus content in the bottom sediments depends on the type of sapropel and reaches $4,6 \%$ on dry matter. Its mobile forms rated from 5 to $33 \%$. Inorganic forms of phosphorus are represented by compounds with iron, aluminum and calcium, as well as sorbed phosphorus on clay particles and organic complexes. The organic forms of phosphorus in sapropel are associated with humic acids and the heavily hydrolyzed portion of organic matter.

The content of potassium oxide, depending on the type of sapropel is up to $3,2 \%$ on dry matter. Metabolic form $-13-19 \%$ of its gross content, or up to $100 \mathrm{mg} / 100 \mathrm{~g}$ of dry sapropel.

Calcium, according to the results of laboratory determinations, is of organic origin and is the main cation of the absorbing complex of sapropel $-100-170 \mathrm{mg} . e q / 100 \mathrm{~g}$. The magnesium content is lower (23-30 $\mathrm{mg}$. eq $/ 100 \mathrm{~g}$ of dry matter) than calcium. Together (calcium and magnesium) play a positive role in reducing the acidity of sapropel in the decomposition of organic matter by microorganisms, which emit carbon dioxide. The generalized results of laboratory determinations indicate that the $\mathrm{pH}$ of sapropel is in the range of 5,5-7,7.

The sulfur content in sapropel is $1,5-2,5 \%$ on dry matter. It is in organic $(70-80 \%)$, sulfate $(2-5 \%)$ and sulfide $(15-20 \%)$ forms of the gross. Elemental sulfur is in very small quantities.

Trace elements are also present in sapropel deposits. Microorganisms that inhabit sapropel have the ability to neutralize the action of pathogenic microorganisms, which is extremely important in the manufacture of substrates.

The raw material base of sapropel in Volyn oblast is represented by 190 deposits with reserves of categories $A+C_{1} 55,067$ million tons, of category $C_{2}-11,296$ million tons [8]. A significant amount of sapropel reserves has been explored in Kovel, Liubeshiv, Liuboml and Shatsk districts. Great prospects for conducting detailed explorations on the basis of exploration and evaluation works open up in Manevychi, Ratne, Starovyzhiv and Turiisk districts. The lakes of oblast are dominated by organic sapropel, mixed organo-limestone, limestone and organo-iron types.

To increase plant productivity, it is necessary to maximize the mobilization of their potential in the process of crop formation. Mineral nutrition is one of the important and regulated factors in solving this problem. Optimization of mineral nutrition of a cultivated plant is achieved only if the plant is provided with the necessary amounts of nitrogen, phosphorus, potassium.

One of the most valuable local raw materials for substrates, which can serve as a source of nutrients for plants is manure. The composition of manure depends on the quality and quantity of feed, species and age of animals etc. When feeding animals succulent feed, the amount of liquid secretions increases. The increase of concentrates in the diet increases the content of nitrogen and phosphorus in the secretions of animals.

According to the statistical report in Volyn oblat (average for 2010-2020, as of October 1) accumulate significant amounts of manure: cattle $-564,2$ thousand tons (given that the duration of the stall period in Volyn oblast is on average 190 days), pigs $-1017,7$ thousand tons and sheep and goats $-21,5$ thousand tons (fig. 1). 


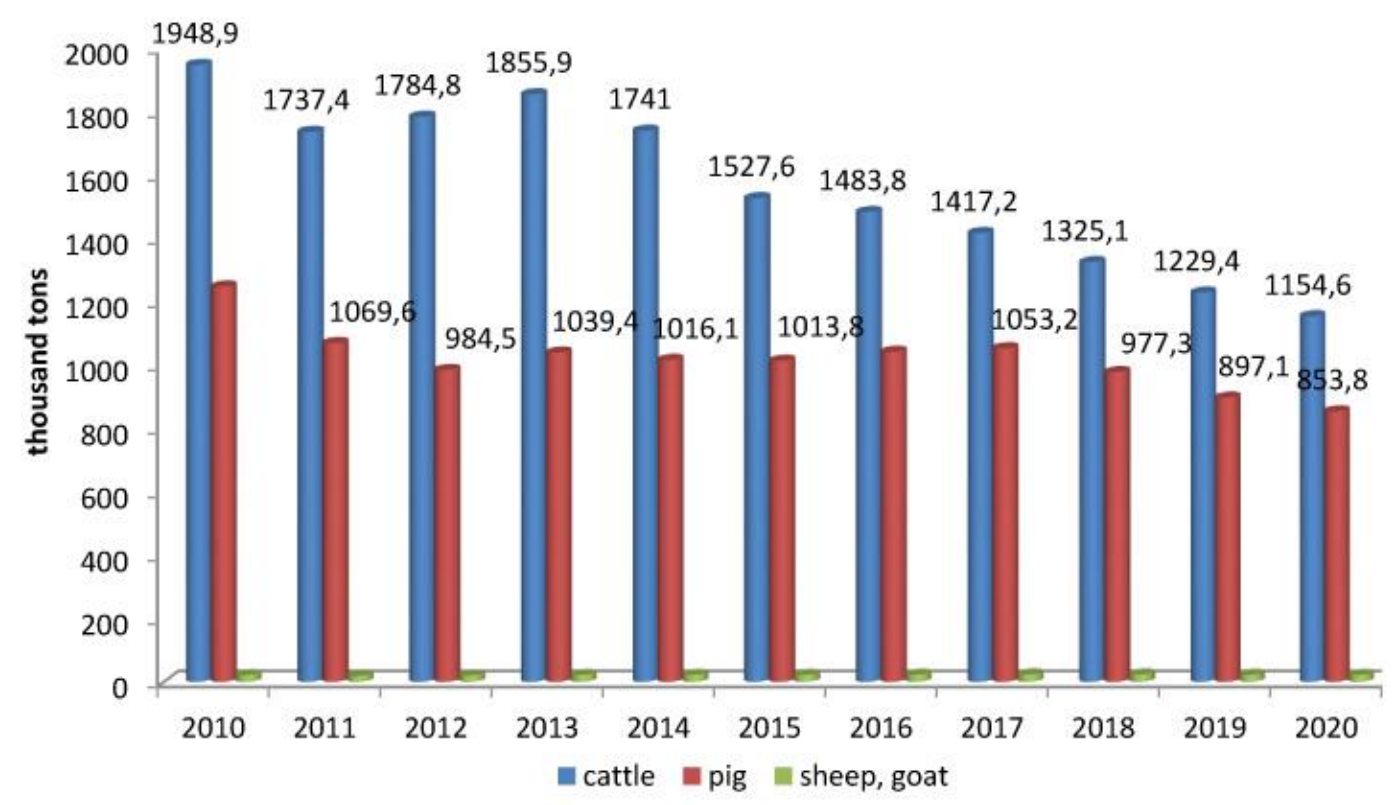

Fig. 1. Average data on the accumulation of semi-rotted manure in Volyn oblast

A high component is also bird droppings, the composition of which depends on the quality and quantity of feed, species and age of birds etc. On average, you can have $0,19 \mathrm{~kg}$ of bird droppings per bird per day. Thus, on average during 2010-2020, 585,3 thousand tons of manure accumulate annually (fig. 2).

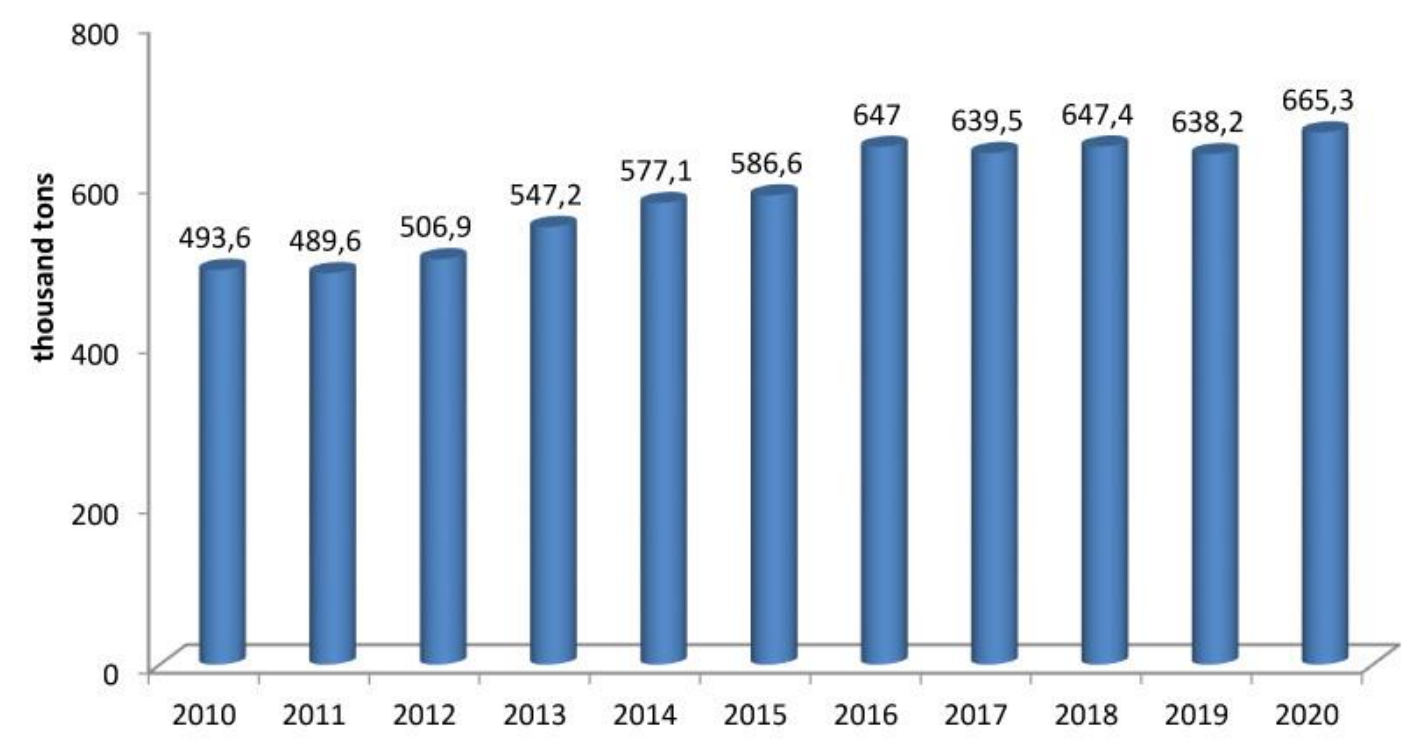

Fig. 2. Average data on the accumulation of bird droppings in Volyn oblast

Carbonate and phosphorus raw materials are also used as components of organic substrates. Carbonate raw materials in oblast are represented by chalk, chalky marl, limestones of the Upper Cretaceous age. In Volyn, 26 deposits of carbonate raw materials were discovered and studied, 9 of which were explored in detail and listed on the balance with chalk reserves of 28903 thousand tons, 17 of which were analyzed and characterized by exploration works -12580 thousand tons.

Phosphorus raw materials are represented by two types of phosphorites - granular and concretionary. Deposits of granular phosphorites are present in Manevychi, Rozhyshche and Kivertsi districts. The projected resources of granular phosphorites are estimated at 6434 million tons of agronomical ore, or 332,9 tons of $\mathrm{P}_{2} \mathrm{O}_{5}$. Deposits of concretionary phosphorites are represented by Ratne deposit, which is located in the north-western part of oblast (Starovyzhiv, Ratne, Kamin-Kashyrsk and Liuboml districts). Projected reserves of concretionary phosphorites are estimated at 16977,8 million tons of agronomical ore, or 7669,2 million tons of $\mathrm{P}_{2} \mathrm{O}_{5}$.

As an organic component, for the manufacture of substrates, you can use industrial waste and utilities. Sewage sludge, which has a high agronomic value, accumulates annually at treatment facilities. According to the State Department of Ecology and Natural Resources in Volyn oblast, in accordance with the technical 
and economic parameters of sewage treatment plants and the actual discharge of return water in oblast during 2018 the accumulation of sewage sludge amounted to 77,8 thousand tons in terms of dry matter.

The industry produces many different wastes that can be used to enrich substrates with nutrients. Proper use of them has a double meaning: on the one hand, it increases the productivity of crops, on the other industrial production becomes more economical. Industrial wastes are used mainly as nitrogen components and only some of them are relatively rich in other nutrients for the manufacture of soil compositions of covered soil. Nitrogen in them is in organically bound form and becomes available to plants after previous mineralization; therefore, this waste must be composted or applied in advance. Such types of products, the accumulation of which is quite significant in oblast, include molasses bard. There are accumulated about 29,4 thousand tons of bards annually, according to the actual production capacity.

An important criterion for the quality of substrates is to ensure optimal air and water regime, which would ensure active root growth and high plant survival. This can be achieved by adding to the substrates loosening components, such as perlite, vermiculite. The use of waste of organic origin is also promising in this direction.

According to the statistical report in Volyn oblast, waste from forestry and woodworking industry, the volume of accumulation of which according to the actual production capacity is (average for 2010-2018) 93,0 thousand tons of branches and bark and 341,5 thousand $\mathrm{m}^{3}$ of industrial chip (fig. 3.).

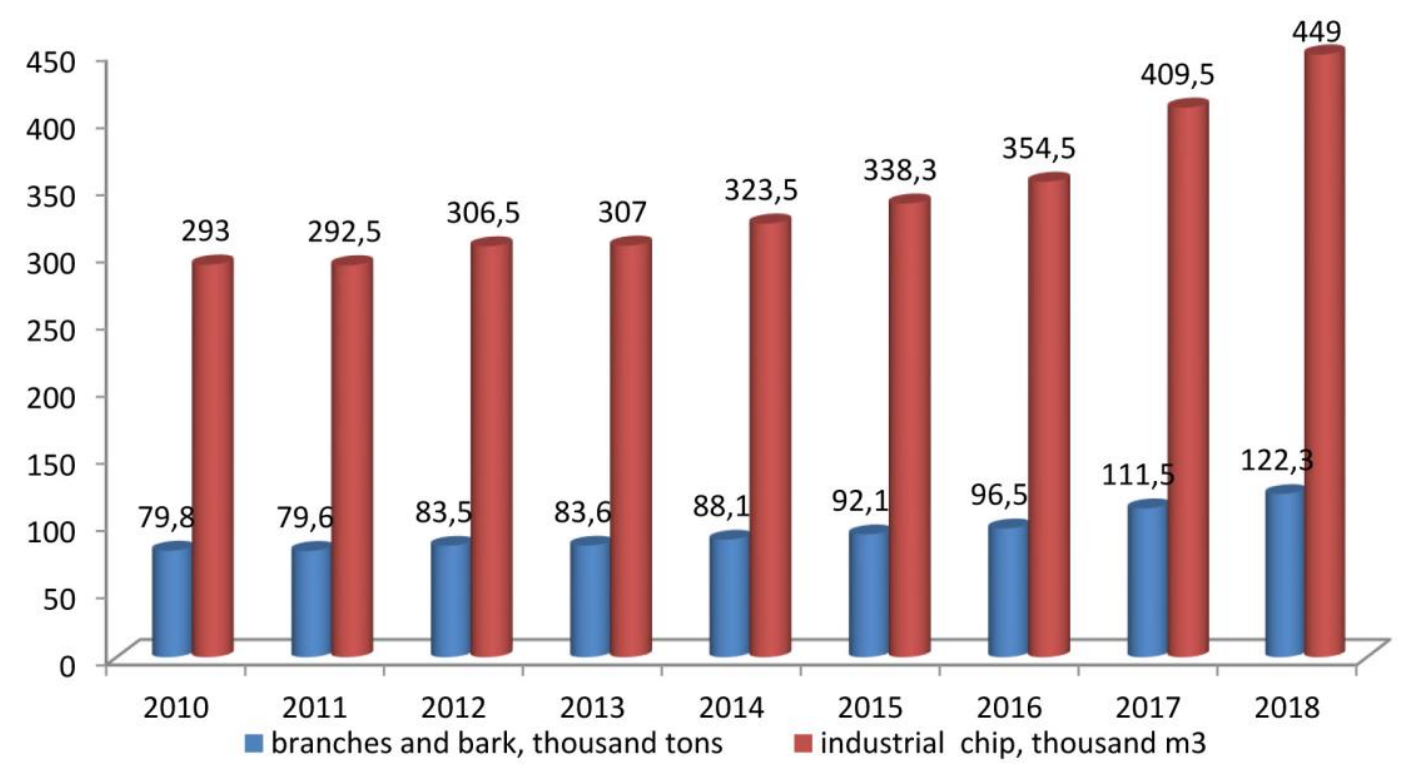

Fig. 3. Average statistical data on the accumulation of forest industry waste in Volyn oblast

Straw is an equally promising loosening component. This component is also an important source of organic and mineral substances for plants. According to statistics, the annual accumulation of cereals straw can be 863,8 thousand tons (average for 2010-2019; fig. 4.).

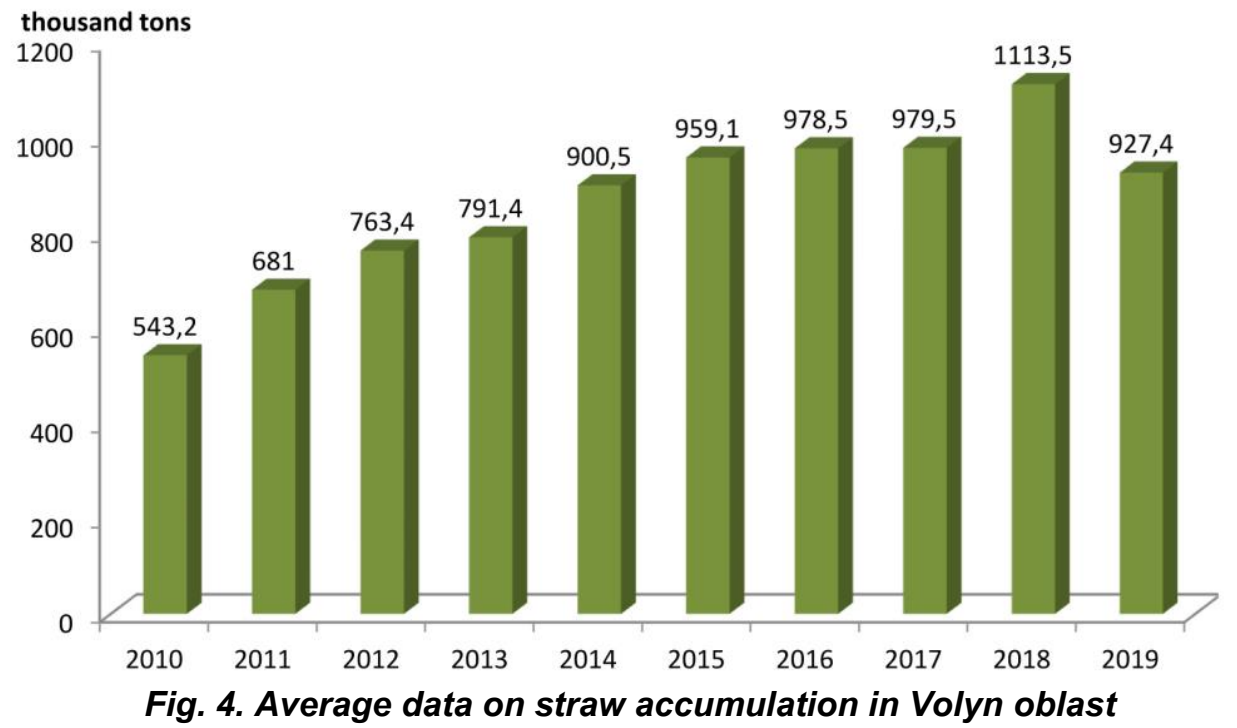


Based on the analysis of available raw materials in Volynoblast, a system for assessing the suitability of local raw materials for the manufacture of soil substrates for growing rare berry crops, based on agrobiological characteristics of plants (Table) [9-11]. Thus, when growing blueberries, the optimal characteristics of the substrates are:

- acid reaction of the soil solution in the range of 3,5-4,5 units;

- substrate density not more than $0,2 \mathrm{~g} / \mathrm{cm}^{3}$;

- ash content not more than 20\%; nitrogen content - 100-150 mg/kg, during fruiting - less;

- phosphorus content - 50-100 mg/kg; potassium content - 120-170 mg/kg.

For growing honeysuckle, the optimal conditions are:

- neutral reaction of the soil solution in the range of 6,0-7,0 units;

- substrate density not more than $1,2 \mathrm{~g} / \mathrm{cm}^{3}$;

- ash content not more than $40 \%$; nitrogen content - 100-150 mg/kg;

- phosphorus content - 50-100 mg/kg;

- potassium content - 120-170 mg/kg.

System for assessing the suitability of the main types of local raw materials for growing rare berry crops

\begin{tabular}{|c|c|c|}
\hline \multirow[t]{2}{*}{ Indicator } & \multicolumn{2}{|c|}{ Culture } \\
\hline & blueberry & honeysuckle \\
\hline \multicolumn{3}{|c|}{ Lowland peat } \\
\hline $\mathrm{pH} \mathrm{KCL}_{\mathrm{L}}$ units. $\mathrm{pH}$ & $6,1 /$ not correspond & $6,1 /$ corresponds \\
\hline substrate, $\mathrm{g} / \mathrm{cm}^{3}$ & $0,48 /$ not correspond & $0,48 /$ corresponds \\
\hline ash, $\%$ & $31,5 /$ correspond & $31,5 /$ corresponds \\
\hline total nitrogen, $\%$ & $2,97 /$ correspond & 2,97/correspond \\
\hline $\begin{array}{l}\text { mobile forms of nitrogen } \\
\left(\mathrm{N}-\mathrm{NO}_{3}+\mathrm{N}-\mathrm{NH}_{4}\right), \mathrm{mg} / \mathrm{kg}\end{array}$ & $137,3 /$ correspond & $137,3 /$ correspond \\
\hline total phosphorus, \% & $0,84 /$ not correspond & $0,84 /$ correspond \\
\hline mobile forms of phosphorus, $\mathrm{mg} / \mathrm{kg}$ & 63,5/correspond & $63,5 /$ correspond \\
\hline total potassium, \% & $0,08 /$ not correspond & $0,08 /$ not correspond \\
\hline mobile forms of potassium, $\mathrm{mg} / \mathrm{kg}$ & $24,0 /$ not correspond & $24,0 /$ not correspond \\
\hline \multicolumn{3}{|c|}{ Transitional peat } \\
\hline pH $\mathrm{pCL}_{\text {, }}$ units. $\mathrm{pH}$ & $4,85 /$ not correspond & 4,85/correspond \\
\hline substrate, $\mathrm{g} / \mathrm{cm}^{3}$ & $0,11 /$ correspond & $0,11 /$ correspond \\
\hline ash, \% & 16,19/correspond & 16,19/correspond \\
\hline total nitrogen, \% & $2,03 /$ correspond & $2,03 /$ correspond \\
\hline $\begin{array}{l}\text { mobile forms of nitrogen } \\
\left(\mathrm{N}-\mathrm{NO}_{3}+\mathrm{N}-\mathrm{NH}_{4}\right), \mathrm{mg} / \mathrm{kg}\end{array}$ & $117,2 /$ correspond & $117,2 /$ correspond \\
\hline total phosphorus, $\%$ & $0,32 /$ not correspond & $0,32 /$ not correspond \\
\hline mobile forms of phosphorus, $\mathrm{mg} / \mathrm{kg}$ & $47,7 /$ not correspond & $47,7 /$ not correspond \\
\hline total potassium, $\%$ & $0,10 /$ not correspond & $0,10 /$ not correspond \\
\hline mobile forms of potassium, $\mathrm{mg} / \mathrm{kg}$ & $21,5 /$ not correspond & $21,5 /$ not correspond \\
\hline \multicolumn{3}{|c|}{ Horse peat } \\
\hline $\mathrm{pH} \mathrm{KCL}_{\mathrm{K}}$, units. $\mathrm{pH}$ & $4,0 /$ correspond & 4,0/not correspond \\
\hline substrate, $\mathrm{g} / \mathrm{cm}^{3}$ & $0,11 /$ correspond & $0,11 /$ correspond \\
\hline ash, $\%$ & $2,7 /$ correspond & $2,7 /$ not correspond \\
\hline total nitrogen, \% & $1,32 /$ correspond & 1,32/correspond \\
\hline $\begin{array}{l}\text { mobile forms of nitrogen } \\
\left(\mathrm{N}-\mathrm{NO}_{3}+\mathrm{N}-\mathrm{NH}_{4}\right), \mathrm{mg} / \mathrm{kg}\end{array}$ & 119,5/correspond & $119,5 /$ correspond \\
\hline total phosphorus, $\%$ & $0,28 /$ not correspond & $0,28 /$ not correspond \\
\hline mobile forms of phosphorus, $\mathrm{mg} / \mathrm{kg}$ & $38,4 /$ not correspond & $38,4 /$ not correspond \\
\hline total potassium, \% & $0,07 /$ not correspond & $0,07 /$ not correspond \\
\hline mobile forms of potassium, $\mathrm{mg} / \mathrm{kg}$ & $13,2 /$ not correspond & $13,2 /$ not correspond \\
\hline \multicolumn{3}{|c|}{ organic sapropel } \\
\hline pH $\mathrm{KCL}_{\text {, units. } \mathrm{pH}}$ & 4,65/correspond & $4,65 /$ not correspond \\
\hline substrate, $\mathrm{g} / \mathrm{cm}^{3}$ & 1,0/not correspond & 1,0/correspond \\
\hline ash, \% & 19,72/correspond & 19,72/correspond \\
\hline total nitrogen, $\%$ & 2,3/correspond & 2,3/correspond \\
\hline $\begin{array}{l}\text { mobile forms of nitrogen } \\
\left(\mathrm{N}-\mathrm{NO}_{3}+\mathrm{N}-\mathrm{NH}_{4}\right), \mathrm{mg} / \mathrm{kg}\end{array}$ & 134,2/correspond & 134,2/correspond \\
\hline total phosphorus, \% & $1,5 /$ correspond & $1,5 /$ correspond \\
\hline
\end{tabular}




\begin{tabular}{|l|c|c|}
\hline mobile forms of phosphorus, $\mathrm{mg} / \mathrm{kg}$ & $112,6 /$ correspond & $112,6 /$ correspond \\
\hline total potassium, $\%$ & $1,4 /$ correspond & $1,4 /$ correspond \\
\hline mobile forms of potassium, $\mathrm{mg} / \mathrm{kg}$ & $87,9 /$ not correspond & $87,9 /$ not correspond \\
\hline $\begin{array}{l}* \\
\text { features of culture }\end{array}$ & in the denominator the indicator is given, in the numerator - correspondence to agrobiological \\
\hline
\end{tabular}

\section{Conclusions}

Statistical analysis of available local raw materials in Volyn oblast shows that the most promising that can be used as the main components for the manufacture of substrates is peat, reserves of which are 143,406 million tons of category $A+B+C_{1}$ and 11,334 million tons of category $C_{2}$, and also sapropel reserves of which are 55,067 million tons of category $A+C_{1}$ and 11,296 million tons of category $C_{2}$. In addition, local resources such as phosphorites, manure, droppings and industrial and municipal wastes can be used to enrich the substrates with nutrients. To improve air and water regime can be used bark, chips and straw.

The developed comprehensive assessment of the suitability of local raw materials is based on the available raw materials of oblast, their main characteristics (density, reaction of soil solution, contents of nitrogen, phosphorus, potassium, ash) and the main agrobiological characteristics of plants. This assessment allows you quickly and efficiently select components for the appropriate type of berry crop.

\section{References}

1. Seriohin, V.K. (2014). Efektyvnist vyrobnytstva produktsii roslynnytstva yak faktor zabezpechennia prodovolchoi bezpeky krainy [Efficiency of crop production as a factor in ensuring food security of the country]. Business Navigator, 1, 99-103. [In Ukrainian].

2. Barinova, M.F., Lashnev, V.I., \& Tolmacheva, V.A. (1985). Maloobemnyy substrat iz sukhikh torfyanykh plit [Low-volume substrate of dry peat slabs]. Potatoes and vegetables, 6, 22-23. [In Russian].

3. Vasilev, A.A. (1999). Fermvey - novoe organicheskoe udobrenie pod kartofel [Farmway is a new organic fertilizer for potatoes]. Bulletin of the Russian Academy of Agricultural Sciences, 5, 36. [In Russian].

4. Volkova, N.A. (2014). Analiz sostoyaniya i razvitiya selskogo khozyaystva odesskogo regiona [Analysis of the state and development of agriculture in Odessa oblast]. Bulletin of TVSU [Tver State University]. Series: Economics and Management, 2(4), 281-289. [In Russian].

5. Pilipenko, K.A. (2017). Orhanichne vyrobnytstvo yak instrument zmitsnennia prodovolchoi bezpeky [Organic production as a tool for strengthening food security]. Bulletin of Berdyansk University of Management and Business, 4, 48-52. [In Ukrainian].

6. Barinova, M.F., Lashnev, V.I., \& Tolmacheva, V.A. (1985). Maloobemnyy substrat iz sukhikh torfyanykh plit [Low-volume substrate of dry peat slabs]. Potatoes and vegetables, 6, 22-23. [In Russian].

7. Glaz, N.V., Kukhturskiy, A.A., \& Ufimtseva, L.V. (2017). Vliyanie sostava pochvogrunta na kachestvo sazhentsev kostochkovykh kultur $v$ konteynerakh [Influence of soil composition on the quality of seedlings of stone crops in containers]. Modern gardening, 1 (21), 36-44. [In Russian].

8. Rehionalna dopovid pro stan dovkillia Volynskoi oblasti u 2018 rotsi [Regional report on the state of the environment of Volyn oblast in 2018]. Lutsk, 2019. Retrieved from https://voladm.gov.ua/article/ regionalna-dopovid-pro-stan-dovkillya/

9. Shevchuk, M.Y., \& Bortnik, T.P. (2017). Lokhyna vysoka: tekhnolohii vyroshchuvannia [Highbush blueberries: growing technologies]. Lutsk: PE Ivaniuk V.P. [In Ukrainian].

10. Shevchuk, M.Y., \& Bortnik, T.P. (2018). Zhymolost yistivna: biolohiia, ahrotekhnika vyroshchuvannia. [Honeysuckle: agricultural cultivation techniques]. Lutsk: PE Ivaniuk V.P. [In Ukrainian].

11. Ochmian, I., Malinowski, R., Kubus, M. et al. (2019). The feasibility of growing highbush blueberry (V. corymbosum L.) on loamy calcic soil with the use of organic substrates. Scientia Horticulturae, 257, 113. 